\title{
Teaching leprosy: the need for knowledge and for the development of attitudes to work
}

\author{
W F ROSS \\ American Leprosy Missions, 1 Broadway, \\ Elmwood Park, NJ 07407, USA
}

Most leprosy programs have three basic purposes:

1. The control of leprosy as a public health problem aiming at prevention of infection of otherwise healthy people;

2. The care and, as far as possible, cure of individual patients;

3. The prevention and alleviation of disability.

For the time being, the strategies available to us for fulfilling these purposes are limited to:

1. Chemotherapeutic isolation of infectious cases, as early as possible in the disease process;

2. Clinical care of individual patients.

It is obvious that the implementation of these strategies requires cooperative action by the patients themselves, the community at large, and workers in the health system as a whole. Given these premises, it is not difficult to draw up a list of professional and non-professional tasks which must be accomplished by different individuals if the goals of the leprosy program are to be met.

So far so good, but there is a danger that in the development of professional tasks, human aspects of leprosy patient care and the need for different people to accept their differences and work together to achieve a common purpose will be lost sight of.

Lists of tasks clearly focus on objective descriptions of a job to be done. What is also needed to balance this are subjective descriptions of the human qualities needed to enable people to relate effectively with others to do those jobs.

In order to convert a job description into such statements in a systematic way, it is useful to have, at least as a check list, a suitable classification of educational objectives. The taxonomy should be comprehensive, and should take into account the different kinds of learning experiences required for 
reaching particular objectives. A taxonomy has been provided by R. G. Carter (1). It is summarized in Table 1 .

Table 1 Sumary of a taxonamy of objectives for professional education

\begin{tabular}{|c|c|c|c|c|}
\hline \multirow[b]{2}{*}{$\begin{array}{l}\text { Personal } \\
\text { qualities }\end{array}$} & $\begin{array}{l}\text { Mental } \\
\text { characteristics }\end{array}$ & $\begin{array}{l}\text { Attitudes } \\
\text { and values }\end{array}$ & $\begin{array}{l}\text { Personality } \\
\text { characteristics }\end{array}$ & $\begin{array}{l}\text { Spiritual } \\
\text { qualities }\end{array}$ \\
\hline & $\begin{array}{l}\text { Openness } \\
\text { Agility } \\
\text { Imagination } \\
\text { Creativity }\end{array}$ & $\begin{array}{l}\text { Things } \\
\text { Self } \\
\text { People } \\
\text { Groups } \\
\text { Ideas }\end{array}$ & $\begin{array}{l}\text { Integrity } \\
\text { Initiative } \\
\text { Industry } \\
\text { Emotional } \\
\text { resilience }\end{array}$ & $\begin{array}{l}\text { Appreciation } \\
\text { Response }\end{array}$ \\
\hline & $\begin{array}{l}\text { Mental } \\
\text { skills }\end{array}$ & $\begin{array}{l}\text { Information } \\
\text { skills }\end{array}$ & $\begin{array}{l}\text { Action } \\
\text { skills }\end{array}$ & $\begin{array}{l}\text { Social } \\
\text { skills }\end{array}$ \\
\hline Skill & $\begin{array}{l}\text { Organization } \\
\text { Analysis } \\
\text { Evaluation } \\
\text { Synthesis }\end{array}$ & $\begin{array}{l}\text { Acquisition } \\
\text { Recording } \\
\text { Remembering } \\
\text { Communication }\end{array}$ & $\begin{array}{l}\text { Manual } \\
\text { Organizing } \\
\text { Decision } \\
\text { making } \\
\text { Problem } \\
\text { solving }\end{array}$ & $\begin{array}{l}\text { Co-operation } \\
\text { Leadership } \\
\text { Negotiation \& } \\
\text { persuasion } \\
\text { Interviewing }\end{array}$ \\
\hline
\end{tabular}

\begin{tabular}{lll}
\hline & Factual knowledge & Experimental knowledge \\
Knowledge & Facts & Experience \\
& Structures & Internalisation \\
& Procedures & Generalization \\
& Concepts & Abstraction \\
& Principles & \\
\hline
\end{tabular}

Cognitive

Affective

Carter categorizes educational objectives into three broad groups :

1. Knowledge (what the practitioner knows).

2. Skills (what the practitioner can do).

3. Personal Qualities (what the practitioner is).

Ideally, any particular course of comprehensive professional training should provide opportunities for achieving objectives in all three categories in a balanced way. This is not always the case. For instance, "In a recent questionnaire addressed to medical students of British medical schools, one of the 
questions asked was the amount of time devoted to teaching knowledge and concepts, skills, and attitutes. In general, the students identified $758-808$ of the time devoted to knowledge and concepts, 208-258 to clinical skills (largely physical rather than psychological skills), while the rest of the time was spent on promoting the view that awareness of one's attitude and behavior towards patients was an important clinical attribute" (2).

clearly, the time allocated to development of personal qualities, including attitudes, is very limited in these schools, though the importance of them is no doubt often discussed and well recognized.

1. Knowledge (What the practitioner knows)

An essential component of any training is the acquisition of knowledge.

Carter divides knowledge into two broad groups.

First, factual knowledge, i.e. knowledge acquired mainly by information transfer through listening and reading. However, factual knowledge may also be acquired by experience, though this is a time-consuming process, effective but not very efficient. The acquisition of factual knowledge occupies an enormous proportion of most training courses and time spent on this could be substantially reduced if trainers were to clearly distinguish between facts students need to know by heart, and facts which students need to know where to find.

Secondly, Carter identifies "experiential knowledge." A good example of what is meant by experiential knowledge is provided by Norman Cousins in his best seller, Anatomy of an Illness. In this book, a correspondent, Carole, says of her doctor, "I don't think my doctor has ever been very ill himself, seriously ill, that is. He doesn't know hov long a day can be, how difficult it is to have goals when nothing happens, how your mind turns on all the things that you aren't supposed to think about, like how you aren't getting any better, and how week after week passes without any progress" (3).

I suggest to you that experiential knowledge of this type is particularly important for leprosy workers. We need to know how the patient feels about his disease. We need to know how the patient feels about himself as a person. We need to understand and accept his loss of self respect, his poor self image, his fear of disability, the sense of loss he suffers 
when his limbs become anesthetic and his despair when he is ostracized by former colleagues just because he has leprosy. Perhaps it is only those who have had leprosy who can really acquire this kind of knowledge.

2. Skills (What the practitioner can do)

As Carter points out, "It is self-evident that there is a world of difference between knowing how to do something and being able to do it competently." However, the development of a skill need not and often does not require a great deal of knowledge. Characteristic of skills is the fact that they are largely acquired by practice, and this is necessarily a time-consuming process.

Carter usefully identifies four broad groups of skills (Table 1). First, mental skills: skills in the manipulation and creation of ideas; second, inforamtion skills: skills which enable us to acquire, store, and communicate information; Third, action skills: skills which include manual or practical skills and also the more intellectual skills used in planning and organization, decision making, and problem-solving. His fourth category is social skills, which he designates as cooperation, leadership, negotiation and counseling skills.

Is this characteristic of skills relevant to the design of training for leprosy work? Many of the named skills certainly are. For instance, the ability to obtain information from individuals and to identify relevant information in case histories is crucial. The ability to make good clinical records is also important, as is ability to share ideas on an informal one-to-one basis or in the more formal delivery of. health education to groups.

Action skills important for field workers include not only manual skills but even, perhaps especially, the ability to organize their own activities, and to plan the effective use of their own time, as well as to make significant decisions about patient care. Social skills, as defined by Carter, are clearly very important to anyone working in health care. It is self-evident that ability to work cooperatively as a member of a team, to negotiate with community leaders, to persuade patients and others to adopt appropriate courses of action are all important.

3. Personal Qualities (What the practitioner is) Finally, Carter identifies four groups of personal qualities: 
namely, mental characteristics, attitudes and values, personality characteristics, and spiritual qualities.

These are much harder to define than either knowledge or skill, but are at least as important in the skillful and creative application of the scientific disciplines of health care to the human problems of leprosy patients.

Health workers have to deal with a wide variety of different situations and different people and often have to solve problems with very inadequate resources. This requires considerable mental agility, openness to new ideas, creativity and resourcefulness, and often the ability to "glory in improvisation." .

The importance of appropriate attitudes and values is self evident. Most of us acquired our attitudes to patients, and even to our work generally, by a process of modeling. My own memories include experiences with the late Professor Charles Leithead and Dr. Paul Brand. I was already a clinician of some years standing when I came to ALERT in 1966, but I trust I shall never forget the care, gentleness and thoroughness which I once saw demonstrated as Professor Charles Leithead examined the abdomen of a patient who had come to him. She was the last patient of the day, at the end of a long and gruelling session in the outpatient department, everyone else had gone home, and she seemed to me to have a trivial complaint - but to Professor Leithead, no appeal for help was trivial.

Nor shall I forget, as a surgical trainee, assisting Dr. Brand to open and clean, with meticulous care, a tiny abcess in a finger tip of one of his patients at Karigiri. He took more care and almost as much time over that procedure as other surgeons took over B.K. amputations.

Those of you who know the field program supervisors at ALERT will not be surprised to hear that again and again, in reviewing subjective evaluations made by trainees, we foundt it was these supervisors who had made the greatest impression on them. These men did not have much to say about appropriate attitudes or motivation or integrity but they exemplified these qualities, and that made talk superfluous.

The importance of the personal characteristics of integrity, initiative, and industry is almost self evident, though difficult to document. However, happily it has been well documented by Huikeshoven and Bijleveld. These social 
scientists developed an opportunity to study "patients and ex-patients of two leprosy field workers (LFW) of a vastly different calibur, one a model of conscientiousness and the other somewhat lax in job performance. There was virtually no defaulter problem at any of the superior leprosy field worker's clinics. Some irregularity of attendance did occur, but of acceptable proportions. The field worker's success must first and foremost be ascribed to his holding of clincs on schedule without fail, and his ability to demonstrate personal concern for the well being of his patients. The contrasting field worker did not always appear at his clinics; when he did, his behavior towards patients was abrupt and authoritarian. Defaulters from his clinics, and even patients who continued to attend had built up grudges against the man. He did not seriously attempt to give health education or to motivate patients to ingest medicine punctually." (4) A later study of DDS ingestion by actual measurement of DDS excreted in urine by patients at the superior worker's clinics "tended to confirm the relatively high quality of his job performance. Not only do his patients come to clinics more dependably than most patients in Western Province, but they take their DDS at home, with commendable regularity, compared with regular attenders at clinics in Mwanza, Tanzania" (5).

Carter calls the fourth group of personal qualities "spiritual qualities". By this, he means "the capacity for awe and wonder -- the ability to appreciate value and respond to the world of nature and the highest levels of human acheivement" and leaves open the possibility that "most important of all is the ability to respond to the one who is the author of all these things". As Carter justly remarks, "These qualities are not given great weight in education." Workers in the field of leprosy, in company with all who practice medicine, are often faced with human courage and tragedy which defy scientific explanation, and many of us have learned to value access to spiritual resources as a vital component of our own mental health as well as a source of support for our patients.

Conclusion

Current approaches to education for the caring professions are often based upon the needs of the people to be served. This is a tremendous advance over subject-based education, and is a powerful educational strategy. However, insofar as educational 
design is based laregly upon the acquisition of abilities to carry out defined tasks, as it often is, and disregards the need for students to acquire willingness to fulfill these tasks with integrity and compassion, it risks producing a cadre of technicians who are competent but uncaring. It is suggested that the use of and expanded taxonomy of educational objectives, such as that proposed by Carter, will be useful to educators, at least as a checklist. It should be helpful in the development of an appropriate balance between training for the acquisition of knowledge and technical skills and opportunites to develop the personal qualities and attitudes necessary for the effective implementation of leprosy programs and the compassionate care of leprosy patients.

\section{References}

1. Carter RG. A taxonomy of objectives for professional education. In Studies in Higher Education; June 1985.

2. Seager P. Curriculi and teaching methods in medical education. Chapt 11 in: Education for the Professions. Ed. Sinclair Goodlad. 20th Annual Conference of the Society for Research into higher Education, 1984 .

3. Cousins, N. Anatomy of an Illness as Perceived by the Patient. Norton, New York, 1979.

4. Huikeshoven $\mathrm{H}$, Bijleveld I. Encouraging results from DDS urine analysis among registered leprosy patients in the Wangas, Kenya: An exception that challenges the rule. Lepr Rev 1978 ; $\underline{49} ; 47-52$.

5. Huikeshoven $H$, de Witt $M$, Soeters A, Eggelte TA, Landheer JE, Leiker DL. ELISA inhibition technique for the demonstration of sulphones in bodu fluids. I - sulphones specific antibofy-enzyme conjugate. Lepr Rev 1979; 50: $275-81$. 